\title{
Effect of cumulative fertilizer dressings on the phosphorus status of mineral soils II Comparison of two phosphorus testing methods
}

\author{
HELINÄ HARTIKAINEN \\ Department of Agricultural Chemistry, University of Helsinki, \\ SF-00710 Helsinki, Finland
}

\begin{abstract}
Soil samples collected from field plots before onset of fertilization trials and after seven years of cultivation with annual $\mathrm{P}$ additions of 0,30 or $60 \mathrm{~kg} \mathrm{ha}^{-1}$, were analyzed for water-soluble $\mathrm{P}\left(\mathrm{P}_{\mathrm{w}}\right)$ and acid $\mathrm{NH}_{4}$-acetate-extractable $\mathrm{P}\left(\mathrm{P}_{\mathrm{AAc}}\right)$. In all soil samples, the $\mathrm{P}$ test values correlated closely $\left(\mathrm{r}=0.93^{* * *}\right)$. However, they differed significantly in the clay soils where $\mathrm{P}_{\mathrm{AAC}}$ amounted to 59-96\% of $\mathrm{P}_{\mathrm{w}}$. In the coarser soils, the acetate solution extracted $70-365 \%$ of the water-soluble $\mathrm{P}$, but the difference between the methods remained insignificant. In both soil groups, the molar ratio of $\mathrm{NH}_{4} \mathrm{~F}-\mathrm{P}$ to oxalate-soluble $\mathrm{Al}$ explained $90 \%$ or more of the variation in the $\mathrm{P}$ test values.

The soil samples were divided into different $\mathrm{P}$ content classes according to the acetate test calibration scheme. In various $P$ classes the test values tended to differ statistically significantly: in the lower classes acetate extracted $\mathrm{P}$ more and in the higher classes less than water did. Only in soils ranked as satisfactory in $\mathrm{P}$ the test values were about equal. When the rating scale limits given for the advisory soil testing were applied to the water extraction, in most soils the difference between the P testing methods was of one P class. The fertilization recommendations based on the acetate and water extraction tests were compared.
\end{abstract}

Index words: $\mathrm{P}$ tests, water extraction, acid acetate extraction

\section{Introduction}

A great deal of fertilizer $\mathrm{P}$ is known to accumulate in acid soils. In Finnish soils, the retention of superphosphate $\mathrm{P}$ by soil constituents and the low solubility of rock phosphate have been demonstrated in detail by Kalla (e.g. 1961, 1963, 1969). With time, the accumulation of $\mathrm{P}$ may alter the rate of fertilizer needed. Although newly added $\mathrm{P}$ is more readily available to plants than residual reserves, the yield response to freshly applied $\mathrm{P}$ decreases when the residual $\mathrm{P}$ level is high (MAttingly and Widdowson 1963). Longterm residual contributions of $\mathrm{P}$ fertilizer to crop yields and $\mathrm{P}$ uptake have been shown in numerous studies (e.g. Campbell 1965, Bailey et al. 1977, Halyorsson and Black 
1985). Thus, it is important that the $\mathrm{P}$ tests used as the basis for $\mathrm{P}$ fertilization recommendations are sensitive enough to describe the changes in $\mathrm{P}$ resources.

A previous paper of HaRTIKAINEN (1989) reported changes in various inorganic $\mathrm{P}$ fractions in soil samples from a series of long-term field experiments as a result of different $\mathrm{P}$ fertilization regimens. In the present study, the same material was used to compare the P test values obtained by the water extraction and by the acid $\mathrm{NH}_{4}$-acetate extraction applied in routine soil testing in Finland. The dependence of the $\mathrm{P}$ test values on inorganic $\mathrm{P}$ fractions was investigated statistically.

\section{Material and methods}

The soil samples were collected from 16 field trials consisting of plots cultivated for seven years without $\mathrm{P}$ addition or fertilized annually with superphosphate in quantities corresponding to 30 or $60 \mathrm{~kg}$ of $\mathrm{P} \mathrm{ha} \mathrm{h}^{-1}$. The control samples were taken from the experimental fields before onset of the trials. The characteristics of the experimental soils and the methods of soil analyses are given in the first part of this study (HARTIKAINEN 1989).

Acetate-soluble $\mathrm{P}\left(=\mathrm{P}_{\mathrm{AAC}}\right)$ was extracted according to VUORINEN and MäKITIE (1955): the air-dried and $2 \mathrm{~mm}$ sieved soil samples were shaken in triplicate for $1 \mathrm{~h}$ with acid $\mathrm{NH}_{4} \mathrm{OAc}\left(0.5 \mathrm{M} \mathrm{CH}_{3} \mathrm{COOH}, 0.5 \mathrm{M} \mathrm{CH}_{3}\right.$ $\mathrm{COONH}_{4}, \mathrm{pH} 4.65$ ) at a soil:solution ratio of $1: 10(\mathrm{w} / \mathrm{v})$. The extracts were analyzed for $\mathrm{P}$ by a molybdenum blue-stannous chloride method of Kalla (1955). Water-soluble P $\left(=\mathrm{P}_{\mathrm{w}}\right)$ was extracted by a modified van der PAAUW and Sissingh method at a soil:solution ratio of 1:60 (w/v) (HARTIKAINEN 1982) and analyzed by a molybdenum blue-ascorbic acid method (ANON. 1969).

\section{Results}

The $\mathrm{P}$ test values in soil samples collected from the experimental field before onset of trials and from plots fertilized in total with 0 , 210 or $420 \mathrm{~kg}$ of $\mathrm{P} \mathrm{ha}{ }^{-1}$ are listed in Table 1. In all soil samples, the acetate-soluble and water-soluble $\mathrm{P}$ were closely correlated $(\mathrm{r}=$

Table 1. $\mathrm{P}$ test values $\left(\mathrm{mg} \mathrm{kg}^{-1}\right)\left(\mathrm{AAc}=\right.$ acid $\mathrm{NH}_{4} \mathrm{OAc}$ test, $\mathrm{W}=$ water extraction test $)$ in the soil samples before and after $\mathrm{P}$ fertilization trials.

\begin{tabular}{|c|c|c|c|c|c|c|c|c|}
\hline \multirow{3}{*}{ Soil } & & & \multicolumn{6}{|c|}{ After total $\mathrm{P}$ addition $\left(\mathrm{kg} \mathrm{ha}^{-1}\right)$ of } \\
\hline & \multicolumn{2}{|c|}{ Before trial } & \multicolumn{2}{|c|}{0} & \multicolumn{2}{|c|}{210} & \multicolumn{2}{|c|}{420} \\
\hline & AAc & W & AAc & w & AAc & w & AAc & w \\
\hline \multicolumn{9}{|c|}{ Clay soils } \\
\hline 1 & 5.0 & 7.0 & 3.8 & 4.2 & 5.5 & 6.3 & 8.5 & 10.5 \\
\hline 2 & 15.5 & 23.8 & 12.7 & 15.1 & 14.8 & 17.7 & 18.3 & 24.2 \\
\hline 3 & 7.3 & 10.3 & 5.3 & 6.7 & 9.0 & 13.7 & 13.3 & 22.4 \\
\hline 4 & 17.5 & 18.2 & 11.5 & 14.4 & 17.5 & 20.4 & 18.3 & 24.2 \\
\hline 5 & 4.9 & 7.2 & 3.5 & 5.6 & 5.0 & 8.0 & 6.8 & 11.6 \\
\hline \multicolumn{9}{|c|}{ Coarser soils } \\
\hline 6 & 12.4 & 9.5 & 10.3 & 9.0 & 11.7 & 10.3 & 12.7 & 10.2 \\
\hline 7 & 4.5 & 6.4 & 3.0 & 3.3 & 5.0 & 6.3 & 7.0 & 9.4 \\
\hline 8 & 16.8 & 19.3 & 10.8 & 13.2 & 16.5 & 21.7 & 24.5 & 32.3 \\
\hline 9 & 29.8 & 32.0 & 26.0 & 31.1 & 34.0 & 41.3 & 36.9 & 45.5 \\
\hline 10 & 5.8 & 2.6 & 5.0 & 2.3 & 7.3 & 3.1 & 8.5 & 3.8 \\
\hline 11 & 9.3 & 4.1 & 8.8 & 3.8 & 11.3 & 5.5 & 13.8 & 7.4 \\
\hline 12 & 10.8 & 6.9 & 8.8 & 6.7 & 10.5 & 8.8 & 10.0 & 7.4 \\
\hline 13 & 9.5 & 9.3 & 7.5 & 6.3 & 9.3 & 7.4 & 13.2 & 12.9 \\
\hline 14 & 4.3 & 3.0 & 4.3 & 1.9 & 6.0 & 2.7 & 7.4 & 3.1 \\
\hline 15 & 7.8 & 3.3 & 8.4 & 2.3 & 10.4 & 3.0 & 10.8 & 3.5 \\
\hline 16 & 10.0 & 13.0 & 10.2 & 9.8 & 14.8 & 14.9 & 17.3 & 19.6 \\
\hline
\end{tabular}


$\left.0.93^{* * *}, \mathrm{n}=64\right)$ and their mean values (11.4 and $11.7 \mathrm{mg} \mathrm{kg}^{-1}$, respectively) were about equal. However, in various textural soil groups these methods seemed to extract $\mathrm{P}$ incongruently: in the clay soils $\mathrm{P}_{\mathrm{AAc}}$ amounted to $59-96 \%$ of $\mathrm{P}_{w}$, whereas in the coarser soils the range was decisively wider, 70$365 \%$. The relationship between the $\mathrm{P}$ test values $\left(\mathrm{mg} \mathrm{kg}^{-1}\right)$ conformed to the equations:

$$
\begin{array}{ll}
\text { clay soils: } & \mathrm{P}_{\mathrm{AAc}}=0.09+0.74 \mathrm{P}_{\mathrm{w}} \\
& \mathrm{R}^{2}=0.90 * * *(\mathrm{n}=20) \\
\text { coarser soils: } & \mathrm{P}_{\mathrm{AAc}}=4.41+0.69 \mathrm{P}_{\mathrm{w}} \\
& \mathrm{R}^{2}=0.92 * * * \quad(\mathrm{n}=44)
\end{array}
$$

Table 2. Rating scale for $\mathrm{P}\left(\mathrm{mg} \mathrm{1}^{-1}\right)$ in soils of different textures (ANON. 1986).

\begin{tabular}{lrr}
\hline & Clay soils & Coarser soils \\
\hline Poor & -1.4 & -1.9 \\
Rather poor & $1.5-2.9$ & $2.0-4.9$ \\
Fair & $3.0-5.9$ & $5.0-9.9$ \\
Satisfactory & $6.0-11.9$ & $10.0-19.9$ \\
Good & $12.0-29.9$ & $20.0-39.9$ \\
High & $30.0-69.9$ & $40.0-69.9$ \\
\hline
\end{tabular}

In fact, the paired t-statistics revealed that the estimates for soil $\mathrm{P}$ obtained by $\mathrm{NH}_{4} \mathrm{OAc}$ extraction and those by water extraction differed significantly in the clay soils, whereas in the coarser ones the differences remained statistically insignificant.

The soil samples were classified as to their $\mathrm{P}$ content according to the advisory $\mathrm{P}$ test calibration scheme given in Table 2 (except that the extractability was expressed in $\mathrm{mg} \mathrm{kg}^{-1}$ ). The rating in Table 3 reveals that a cumulative $\mathrm{P}$ addition of $210 \mathrm{~kg} \mathrm{ha}^{-1}$ did not affect the $\mathrm{P}_{\mathrm{AAc}}$ concentration classes of the clay soils, but raised them in four coarser soils (7, 11, 14 and 15) that had initially been ranked as fair or rather poor in $\mathrm{P}$. When the water extraction results were interpreted by using the $\mathrm{P}$ level limits given for the $\mathrm{NH}_{4} \mathrm{OAc}$ extraction test, the $\mathrm{P}$ class was raised in five soils $(3,6,8,9$ and 11$)$ that had originally been categorized as rather poor to good in $\mathrm{P}$ (Table 3 ). Very heavy $\mathrm{P}$ dressings (totally $420 \mathrm{~kg} \mathrm{ha}^{-1}$ ) were needed in five soils to upgrade the $\mathrm{P}$ class according to the $\mathrm{NH}_{4} \mathrm{OAc}$ extraction, and in one soil accord-

\begin{tabular}{|c|c|c|c|c|c|c|c|c|}
\hline \multirow{3}{*}{ Soil } & & & \multicolumn{6}{|c|}{ After total $\mathrm{P}$ addition $\left(\mathrm{kg} \mathrm{ha}^{-1}\right)$ of } \\
\hline & \multicolumn{2}{|c|}{ Before trial } & \multicolumn{2}{|c|}{0} & \multicolumn{2}{|c|}{210} & \multicolumn{2}{|c|}{420} \\
\hline & $\mathrm{AAc}$ & W & $\mathrm{AAc}$ & W & AAc & W & $\mathrm{AAc}$ & W \\
\hline \multicolumn{9}{|c|}{ Clay soils } \\
\hline 1 & 3 & 4 & 3 & 3 & 3 & 4 & 4 & 4 \\
\hline 2 & 5 & 5 & 5 & 5 & 5 & 5 & 5 & 5 \\
\hline 3 & 4 & 4 & 3 & 4 & 4 & 5 & 5 & 5 \\
\hline 4 & 5 & 5 & 4 & 5 & 5 & 5 & 5 & 5 \\
\hline 5 & 3 & 4 & 3 & 3 & 3 & 4 & 4 & 4 \\
\hline \multicolumn{9}{|c|}{ Coarser soils } \\
\hline 6 & 4 & 3 & 4 & 3 & 4 & 4 & 4 & 4 \\
\hline 7 & 2 & 3 & 2 & 2 & 3 & 3 & 3 & 3 \\
\hline 8 & 4 & 4 & 4 & 4 & 4 & 5 & 5 & 5 \\
\hline 9 & 5 & 5 & 5 & 5 & 5 & 6 & 5 & 6 \\
\hline 10 & 3 & 2 & 3 & 2 & 3 & 2 & 3 & 2 \\
\hline 11 & 3 & 2 & 3 & 2 & 4 & 3 & 4 & 3 \\
\hline 12 & 4 & 3 & 3 & 3 & 4 & 3 & 4 & 3 \\
\hline 13 & 3 & 3 & 3 & 3 & 3 & 3 & 4 & 4 \\
\hline 14 & 2 & 2 & 2 & 1 & 3 & 2 & 3 & 2 \\
\hline 15 & 3 & 2 & 3 & 2 & 4 & 2 & 4 & 2 \\
\hline 16 & 4 & 4 & 4 & 3 & 4 & 4 & 4 & 4 \\
\hline
\end{tabular}

Table 3. Rating of soil samples for $\mathrm{P}$ according to the acid $\mathrm{NH}_{4} \mathrm{OAc}$ test (AAc) and the water extraction test (W) before and after $\mathrm{P}$ fertilization trials $(1=$ poor, $2=$ rather poor, $3=$ fair, $4=$ satisfactory, $5=$ good, 6 = high). 
Table 4. Correlation coefficients for the relation between the P test values and inorganic P fraction characteristics.

\begin{tabular}{|c|c|c|c|c|c|c|}
\hline \multirow{2}{*}{ Test } & \multirow{2}{*}{ Soil group } & \multicolumn{3}{|c|}{ P extracted sequentially by } & \multirow[b]{2}{*}{$\mathrm{NH}_{4} \mathrm{~F}-\mathrm{P} / \mathrm{Al}$} & \multirow[b]{2}{*}{$\mathrm{NaOH}-\mathrm{P} / \mathrm{Fe}$} \\
\hline & & $\mathrm{NH}_{4} \mathrm{~F}$ & $\mathrm{NaOH}$ & $\mathrm{H}_{2} \mathrm{SO}_{4}$ & & \\
\hline \multicolumn{7}{|l|}{$P_{\text {AAc }}$} \\
\hline & Clays & $0.90^{* * *}$ & $0.91^{* * *}$ & 0.37 & $0.95^{* * *}$ & $0.95^{* * *}$ \\
\hline & Coarser soils & 0.18 & 0.19 & $0.47^{* *}$ & $0.95^{* * *}$ & $0.45^{* *}$ \\
\hline & All soils & $0.31^{*}$ & $0.28^{*}$ & $0.45^{* *}$ & $0.95^{* * *}$ & $0.51^{* * * *}$ \\
\hline \multicolumn{7}{|l|}{$P_{w}$} \\
\hline & Clays & $0.85^{* * *}$ & $0.88^{* * *}$ & 0.38 & $0.95^{* * *}$ & $0.86^{* * *}$ \\
\hline & Coarser soils & 0.10 & 0.04 & $0.55^{* * *}$ & $0.97^{* * *}$ & $0.44 * *$ \\
\hline & All soils & 0.13 & 0.20 & $0.52 * * *$ & $0.94^{* * *}$ & $0.54 * * *$ \\
\hline
\end{tabular}

ing to the water extraction. There were five soils (fair to good in $\mathrm{P}_{\mathrm{AAc}}$ or rather poor to good in $\mathrm{P}_{\mathrm{w}}$ ) in which not even this dosage was enough to affect the rating.

In order to compare the testing methods in more detail, the relation between $\mathrm{P}_{w}$ and $\mathrm{P}_{\text {AAc }}$ was studied also within individual $P$ classes. The correlation coefficients were: rather poor or fair soils $r=0.12(n=27)$, satisfactory soils $\mathrm{r}=0.58^{* *}(\mathrm{n}=24)$ and good soils $\mathrm{r}=0.95^{* * *}$ $(\mathrm{n}=13)$. The paired $\mathrm{t}$-statistics revealed, however, that the $\mathrm{P}$ test values did not differ in soils classified as satisfactory, whereas they differed significantly in soils of the other categories: in the lower $\mathrm{P}$ classes acetate tended to extract more, and in the higher classes it extracted less than water did.

The correlation coefficients for the relation between the $\mathrm{P}$ test values and the inorganic $\mathrm{P}$ fractions investigated in the first part of this study (HaRTIKAINEN 1989) are presented in Table 4 . In the clay soils, both $\mathrm{P}$ test values correlated closely with the $\mathrm{P}$ extracted by $\mathrm{NH}_{4} \mathrm{~F}$ and $\mathrm{NaOH}$, in the coarser soils with the $\mathrm{P}$ soluble in $\mathrm{H}_{2} \mathrm{SO}_{4}$. However, the molar ratio of $\mathrm{NH}_{4} \mathrm{~F}-\mathrm{P}$ to oxalate-soluble $\mathrm{Al}$ was a factor that explained the variation in both test values to a marked degree, whereas the corresponding molar ratio $\mathrm{NaOH}-\mathrm{P} / \mathrm{Fe}$ explained the variation only in the clay soils. Accordingly, the increases in the $\mathrm{P}$ test values seemed to be related to the increase in the $\mathrm{NH}_{4} \mathrm{~F}-\mathrm{P}$ : in the clay soils the $\mathrm{r}$ values were $0.86^{* *}$ and $0.67^{*}$ for $\mathrm{P}_{\mathrm{w}}$ and $\mathrm{P}_{\mathrm{AAc}}$; the respective values in the coarser soils were $0.50^{*}$ and $0.75^{* * *}$.

\section{Discussion}

The affinity of a given inorganic $\mathrm{P}$ fraction to desorb $\mathrm{P}$ into water has been found to be controlled by the quantity of the corresponding sorption component (HARTIKAINEN 1982). This seemed to hold true also for acid $\mathrm{NH}_{4}$-acetate soluble $\mathrm{P}$ which was closely correlated with the molar ratio of $\mathrm{NH}_{4} \mathrm{~F}-\mathrm{P}$ ("Al-P") to oxalate-soluble Al. Furthermore, both $\mathrm{P}$ test values correlated with the ratio of $\mathrm{NaOH}-\mathrm{P}$ ("Fe-P') to oxalate-soluble $\mathrm{Fe}$ in the clay soils but not in the coarser soils, where the variation in the Fe content was very wide and, thus, despite the same "saturation degree" the soil samples might markedly differ in their content of free active sorption agents (cf. Hartikainen 1982). In the first part of this study (HARTIKAINEN 1989) the $\mathrm{H}_{2} \mathrm{SO}_{4}$ soluble fraction was found to be quite inactive, for which reason $\mathrm{P}$ was hardly desorbed from these reserves, at least in the water extraction.

The sorption of $\mathrm{P}$ is reversible with respect to changes in $\mathrm{pH}$, and increases as the $\mathrm{pH}$ decreases (e.g. Muljadi et al. 1966). The differences in $\mathrm{P}$ quantities extracted by the methods compared may partly be attributable to the dissimilar $\mathrm{pH}$ of the contacting solution. In the water extraction, the $\mathrm{pH}$ depends largely on the soil acidity. In the acetate method, on the contrary, the extraction takes place in acid buffered ( $\mathrm{pH} 4.65$ ) conditions, which may enhance the resorption of dissolved P. In fact, in soils with $\mathrm{pH}>5.0, \mathrm{P}_{\mathrm{w}}$ was higher than $\mathrm{P}_{\mathrm{AAc}}$. 
Both P test values were, on average, of the same magnitude. Average extraction results or regression equation may, however, give too approximate estimates of the equality of two methods in routine soil testing. From the practical point of view, it is important to know how markedly the methods differ in individual soil samples. When the extraction results were interpreted by using the same scale of $\mathrm{P}$ classes, half of the control samples were identically ranked by both $\mathrm{P}$ testing methods, three control samples were ranked higher and five soils were ranked lower by water than by $\mathrm{NH}_{4} \mathrm{OAc}$. A similar variation in the reactivity of soil $\mathrm{P}$ with respect to these extractants can be seen in the data published by SiPPOLA and JAAKKOLA (1980).

The soil material was too limited to allow any far-reaching conclusions to be drawn, but the different fertilization backgrounds seemed to change $\mathrm{P}_{\mathrm{w}}$ more than $\mathrm{P}_{\mathrm{AAc}}$, and to alter the $\mathrm{P}$ classes more sensitively when the rating was based on $\mathrm{P}_{\mathrm{w}}$ instead of on $\mathrm{P}_{\mathrm{AAc}}$. This response is similar to that found by Prummel (1980) in a long-term fertilization study where the P-citr (1\% citric acid) and P-AL (ammonium lactate-acetic acid) increased less than $\mathrm{P}_{w}$. In the present study, the changes found in a given soil by the $\mathrm{NH}_{4} \mathrm{OAc}$ extraction test generally were not obtainable by the water extraction test, and vice versa. According to the $\mathrm{NH}_{4} \mathrm{OAc}$ test, long-term cultivation without $\mathrm{P}$ fertilization lowered the P class in three soils (3, 4 and 12$)$ which had originally been rich in secondary $\mathrm{P}$ and had been ranked as satisfactory or good. Water extraction revealed a reduction in five soils $(1,5,7,11$ and 16) the P status of which ranged from rather poor to satisfactory.

\section{References}

ANON. 1969. Juoma- ja talousveden tutkimusmenetelmăt. Elintarviketutkijain Seura. 169 p. Helsinki.

ANON. 1986. Viljavuustutkimuksen tulkinta peltoviljelyssä. Viljavuuspalvelu Oy.
If the ranges used for the $\mathrm{P}$ rating scale are the same regardless of the $P$ extraction method, the rating for many samples differs by one class. This, in turn, means that fertilization recommendations based on the $\mathrm{NH}_{4} \mathrm{OAc}$ extraction test are not necessarily valid in the system based on the water extraction test. For instance, if the data in Table 3 are employed for fertilization recommendations according to the advisory soil test calibration scheme (ANON. 1986), in the clay soil samples the $P$ fertilizer requirement for grasses, cereals, leguminous or oil plants is, on average, $10 \mathrm{~kg}$ $\mathrm{ha}^{-1}$ lower in the $\mathrm{P}_{\mathrm{w}}$ than in the $\mathrm{P}_{\mathrm{AAc}}$ system. In coarser soils, on the contrary, the rating system based on $\mathrm{P}_{\mathrm{w}}$ more often increases the recommended $\mathrm{P}$ dosages. However, in two subsamples of soil 9 there would be no need for $\mathrm{P}$ addition.

The most striking difference between the rating systems was found in soil 15: the water extraction ranked its $\mathrm{P}$ level as being rather poor irrespective of the fertilization history, whereas according to the $\mathrm{NH}_{4} \mathrm{OAc}$ extraction test it was fair and further improved by fertilization. In practice, this means that the $\mathrm{P}$ fertilization recommendations for most crops would differ by $20 \mathrm{~kg} \mathrm{ha}^{-1}$. The superiority of $\mathrm{NH}_{4} \mathrm{OAc}$ to water in extracting $\mathrm{P}$ from this soil and the differences found in the many other samples suggest that the extractability of $\mathrm{P}$ by the solutions compared are controlled by dissimilar factors.

Acknowledgement. The author wishes to thank Prof. Paavo Elonen and Dr. Into Saarela, Agricultural Research Centre, and the staff of the research stations for their help in collecting the soil samples. The financial support of the Academy of Finland is gratefully acknowledged.

Bailey, L.D., Spratt, E.D., Read, D.W.L., Warder, F.G. \& Ferguson, W.S. 1977. Residual effects of phosphorus fertilizer for wheat and flax grown on chernozemic soils in Manitoba. Can. J. Soil Sci. 57: 
$263-270$.

CAmpbell, R.E. 1965. Phosphorus fertilizer residual effects on irrigated crops in rotation. Soil Sci. Soc. Amer. Proc. 29: 67-70.

Halvorsson, A.D. \& Black, A.L. 1985. Fertilizer phosphorus recovery after seventeen years of dryland cropping. Soil Sci. Soc. Amer. J. 49: 933-937.

Hartikainen, H. 1982. Water soluble phosphorus in Finnish mineral soils and its dependence on soil properties. J. Scient. Agric. Soc. Finl. 54: 89-98.

Hartikainen, H. 1989. Effect of cumulative fertilizer dressings on the phosphorus status of mineral soils. I Changes in inorganic phosphorus fractions. J. Agric. Sci. Finl. 61: 55-59.

KAILA, A. 1955. Studies on the colorimetric determination of phosphorus in soil extracts. Acta Agr. Fenn. 83: $25-47$.

KaILA, A. 1961. Fertilizer phosphorus in some Finnish mineral soils. J. Scient. Agric. Soc. Finl. 33: 131-139.

KAILA, A. 1963. Fertilizer phosphorus in various fractions of soil phosphorus. J. Scient. Agric. Soc. Finl. 35: 36-46.

KAILA, A. 1969. Residual effect of rock phosphate and superphosphate. J. Scient. Agric. Soc. Finl. 41: $82-88$.

Mattingly, G.E.G. \& Widdowson, F.V. 1963. Residual value of superphosphate and rock phosphate on an acid soil. 1. Yields and phosphorus uptake in the field. J. Agric. Sci. 60: 394-407.

Muljadi, D., Posner, A.M. \& Quirk, J.P. 1966. The mechanism of phosphate adsorption by kaolinite, gibbsite and pseudoboehmite. I The isotherms and effect of pH on adsorption. J. Soil Sci. 17: 212-228.

Prummel, J. 1980. Fertilizer regime and changes in the phosphate and potash status of a silty marine clay soil during 25 years. Fertilizer Research 1: 95-101.

SipPOLA, J. \& JAAKKOLA, A. 1980. Maasta eri menetelmillă mäăritetyt typpi, fosfori ja kalium lannoitustarpeen osoittajina astia- ja kenttăkokeissa. Maatalouden Tutkimuskeskus. Maanviljelyskemian ja -fysiikan laitos. Tiedote n:o 13.

Vuorinen, J. \& MÄ́ritie, O. 1955. The method of soil testing in use in Finland. Agrogeol. Publ. 63: 1-44.

Ms received July 25,88

\section{SELOSTUS}

\section{Pitkäaikaisen superfosfaattilannoituksen vaikutus kivennäismaiden fosforitilaan II Kahden uuttotestin vertailu}

\author{
Helinä Hartikainen \\ Helsingin yliopisto, Maanviljelyskemian laitos, \\ $00710 \mathrm{Helsinki}$
}

Tutkimuksessa vertailtiin vesiuutolla ja viljavuusanalyysissä käytettävällä happamalla asetaattiuutolla saatuja fosforin testiarvoja. Maanäytteet oli koottu Maatalouden Tutkimuskeskuksen eri tutkimusasemilla olleesta 16 fosforilannoituskokeesta ruuduilta, joiden 7 vuoden aikana saama vuosittainen superfosfaattilannoitus oli 0 , 30 ja 60 kg P:a ha-1. Tutkimuksen ensimmäisessä vaiheessa oli selvitetty eri lannoituskäsittelyjen aiheuttamat muutokset epăorgaanissa fosforifraktiossa.

Karkeista kivennäismaista asetaatti uutti fosforia keskimäärin yhtä paljon, mutta savimaista vähemmän kuin vesi. Savimaiden ryhmässä uuttomenetelmien vălinen ero oli tilastollisesti merkitsevä. Kun maanäyteaineisto jaettiin viljavuusanalyysin tulkintaohjeiden mukaisiin viljavuusluokkiin, eri uuttomenetelmien todettiin antavan suunnilleen samansuuruisia tuloksia vain fosforitilaltaan tyydyttäviksi luokitelluissa maissa. Alemmissa viljavuusluokissa asetaatti pyrki uuttamaan fosforia tehokkaammin ja ylemmässä luokassa huonommin kuin vesi.

Fosforin văheneminen tai kertyminen näytti kuitenkin vaikuttavan suhteellisen văhän viljavuustutkimuksen mukaiseen fosforiluokitukseen; lannoittamattomissa koejäsenissä viljavuusluokka laski kahden savimaan ja vain yhden karkean maan kohdalla. Kohtalainen lannoitus (30 kg P) ei vaikuttanut savimaiden luokitukseen lainkaan, mutta karkeiden maiden ryhmässä nosti sitä neljässă tapauksessa. Kun vesi- ja asetaattiuuton tuloksia tulkittiin kảyttămällă samoja luokitusrajoja, uuttotestien antama käsitys maan fosforitilasta poikkesi usein yhdellä fosforiluokalla. Useimpien viljelykasvien kohdalla eron aiheut-

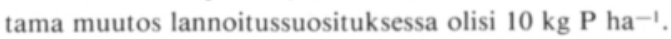

